Bartosz Murawski

SWPS Uniwersytet Humanistycznospołeczny

\title{
Marvel kręci filmy. \\ Shared universe jako nowy trend w kinie hollywoodzkim
}

W lipcu 2015 roku miał premierę Ant-Man (reż. Peyton Reed), dwunasta część filmowego cyklu opowieści o superbohaterach określanego mianem Marvel Cinematic Universe (MCU). Wiadomo już, że wytwórnia Marvel Studios jeszcze przez przynajmniej kilka lat będzie dokładała kolejne elementy do swojej dochodowej franczyzy - plany studia przewidują od dwóch do trzech premier rocznie, a zapowiedzi realizacji kolejnych projektów sięgają końca drugiej dekady XXI wieku (Cecchini 2015).

Olbrzymi sukces finansowy i rzesze oddanych fanów blockbusterów spod szyldu Marvela zapoczątkowały nową modę w hollywoodzkim kinie: wytwórnie zapragnęły mieć własne, wzorowane na modelu marvelowskim shared universe rozbudowane, fikcyjne uniwersum, w którym toczy się akcja serii filmów niekoniecznie ściśle powiązanych ze sobą fabularnie.

Studio Warner Bros. wraz z należącym do tej samej korporacji Time Warner wydawnictwem DC Comics, począwszy od filmu Człowiek ze Stali (Man of Steel, 2013, reż. Zack Snyder) rozpoczęło budowę własnego shared universe określanego jako DC Extended Universe. Rozszerzeniu ulegnie także magiczny świat Harry'ego Pottera - w przygotowaniu jest nowa filmowa trylogia, niepowiązana fabularnie z główną serią. Universal natomiast, nie mając praw do znanych superbohaterów, sięgnął do katalogu klasycznych potworów i postanowił wokół niego stworzyć Monster Universe. Pierwszym filmem nowej serii jest Dracula $\mathrm{Hi}$ storia Nieznana (Dracula Untold, 2014, reż. Gary Shore). To tylko kilka przykładów planów wytwórni hollywoodzkich, wybranych spośród licznych doniesień prasowych (Collinson 2015; Parrish 2015).

Jest niemal pewne, że kino wysokobudżetowe w najbliższych latach będzie stało pod szyldem shared universe, warto zatem zapoznać się bliżej z cechami tej strategii, a najlepiej zrobić to poprzez analizę jego sztandarowego przykładu Marvel Cinematic Universe. 


\section{Shared universe - zarys zagadnienia}

Shared universe jest koncepcją, która najlepiej rozwinęła się na łamach komiksów wydawanych przez dwa największe przedsiębiorstwa w branży: Marvel Comics (tak zwany Marvel Universe) i DC Comics (DC Universe), chociaż można znaleźć wcześniejsze przykłady chociażby w literaturze. Termin ten w języku polskim oznacza „współdzielone uniwersum” lub „wspólny wszechświat”, a rosnącą popularność zawdzięcza przede wszystkim fandomom, czyli grupom fanów komiksów i kręconych na ich podstawie filmów czy seriali, które publikują wspomniane wcześniej wydawnictwa.

Krótko mówiąc, shared universe jest fikcyjnym wszechświatem, przedstawionym na łamach książek, komiksów, filmów, seriali czy gier, który jest kreowany przez wielu twórców jednocześnie. Ich dzieła są względem siebie komplementarne, równoważne, a wydarzenia i postacie $\mathrm{w}$ nich opisane są jedynie fragmentami większej fikcyjnej rzeczywistości z własną mitologią, historią i prawami. Twórcy partycypujący w kreacji shared universe muszą uwzględniać wydarzenia przedstawione $w$ innych dziełach tak, aby nie naruszyć podstaw świata przedstawionego i nie doprowadzić do jego dekompozycji (TV Tropes 2015).

Gdy w połowie XX wieku krytycy z czasopisma "Cahiers du Cinéma” wprowadzali do dyskursu filmoznawczego teorię autora, wskazywali reżysera jako tę osobę, która nadaje filmom charakterystyczny, rozpoznawalny styl (Helman 2010). W przypadku shared universe rolę autora przejmuje oddelegowany przez studio producent, który trzyma pieczę nad poszczególnymi projektami. Wpływ reżysera zostaje ograniczony - ma on zrealizować koncepcję ustaloną przez producentów, a jego film powinien wpisać się w schematy opracowane w ramach serii. To producent decyduje, jakich ludzi zatrudni do realizacji projektu, $w$ jakim kierunku ma zmierzać seria, a także jaką stylistykę ma przyjąć. Shared universe powstaje zatem nie $\mathrm{w}$ wyniku namysłu i prac autora-reżysera, lecz jest rezultatem decyzji wytwórni filmowej i ekosystemu korporacji, do której ona należy ${ }^{1}$.

Aby wskazać, czym różni się shared universe od zwykłego świata fikcyjnego przedstawionego $\mathrm{w}$ filmach, można posłużyć się przykładem. Akcja filmów Quentina Tarantino toczy się w tym samym uniwersum, a dla uważnych widzów reżyser i scenarzysta $w$ jednej osobie umieścił wiele odniesień do swoich pozostałych dzieł (Coolidge 2013). To on sprawuje pieczę nad treścią wyreżyserowanych przez siebie filmów, decyduje też o tym, w jaki sposób będą się one łączyć. Jest autorem w klasycznym sensie. Jego filmy mogą powstawać w różnych wytwórniach, ale reżyser-autor zachowa przy tym pełną kontrolę kreatywną nad swoimi dziełami - on stanowi ich spoiwo.

Inaczej sprawa wygląda $\mathrm{w}$ przypadku shared universe. Poszczególne dzieła tworzą różni reżyserzy i scenarzyści, a sposób, w jaki łączą się ze sobą, jest ustalany przez producentów i marketingowców. To wytwórnia zachowuje kontrolę kreatywną nad procesem produkcji i to ona jest spoiwem poszczególnych części serii. O ile więc $w$ obu wypadkach mamy do czynienia $\mathrm{z}$ fikcyjnymi światami wykreowanymi w licznych dziełach filmowych, o tyle zasadnicze różnice leżą w procesie produkcji i uwarunkowaniach biznesowych.

${ }^{1} \mathrm{O}$ sposobie funkcjonowania hollywoodzkiego modelu kina i korporacyjnych zależnościach pisał Marcin Adamczak (2010: 29-74). 
Bardzo ważną kwestię stanowią prawa autorskie, których dysponentami są studia filmowe. Najczęściej mają one licencje na adaptacje filmowe dzieł literackich bądź komiksów i w ten sposób zapewniają sobie prawo do postaci czy opisanych tam historii. Oczywiście w ramach shared universe mogą pojawiać się także oryginalne projekty, niekoniecznie będące adaptacją wcześniej opublikowanych tekstów. Czasami dochodzi do kuriozalnych sytuacji i sporów, gdy na przykład w filmie nie można użyć konkretnego słowa lub nie można wspomnieć o wydarzeniach, które w oryginalnym tekście stanowiły kanon.

W przeciwieństwie do tradycyjnych franczyz filmowych shared universe nie jest ograniczone chronologią zdarzeń bądź losami jednego bohatera. To świat przedstawiony jest elementem wiążącym fabularnie poszczególne części serii, nie zaś postacie, chociaż nie można bagatelizować ich znaczenia. Tym samym historie prezentowane w poszczególnych odsłonach nie muszą zachowywać ciągłości. Owa nielinearność pozwala przedstawiać w kolejnych odsłonach serii wydarzenia, które działy się równolegle do siebie. Przykładem tradycyjnej franczyzy może być seria Gwiezdnych wojen, na którą składa się obecnie sześć filmów ${ }^{2}$. Ich akcję można pokazać chronologicznie na jednej linii czasowej, gdy tymczasem w shared universe takich linii może być wiele, a będą się one przecinać od czasu do czasu w ramach tak zwanych crossoverów.

Istotnym aspektem shared universe jest narracja transmedialna ${ }^{3}$, czyli snucie opowieści na różnych platformach medialnych, takich jak filmy kinowe, seriale telewizyjne, gry komputerowe czy powiązane z nimi komiksy bądź książki. Są one pełnoprawnymi źródłami wiedzy o świecie przedstawionym i w równym stopniu partycypują w jego kreacji. W przeciwieństwie na przykład do serii Harry Potter, gdzie zarówno filmy, jak i gry były adaptacjami poszczególnych części powieści stanowiącej ich fundament, w shared universe poszczególne narracje uzupełniają się komplementarnie, a nie adaptują tej samej historii na potrzeby różnych mediów.

Przede wszystkim shared universe cieszy się ostatnio w Hollywood taką popularnością, ponieważ jest świetnym źródłem zarobku dla wytwórni, a jednocześnie minimalizują ryzyko. Kolejne odsłony cyklu są szeroko komentowanymi wydarzeniami w kulturze popularnej, zaś same postacie wykraczają daleko poza ekrany kin i telewizorów. Zjawisko prosumpcji ${ }^{4}$ pojawia się, gdy fani filmów i postaci tworzą własne wariacje na ich temat (fanfiction, teledyski, grafiki itp.). Chociaż działania takie często balansują na granicy złamania praw autorskich, to w praktyce wpływają na korzyść wytwórni zarówno w zakresie reklamy i marketingu, jak i podkręcania zainteresowania kolejnymi produkcjami.

${ }^{2}$ Na serię składają się: Gwiezdne wojny: Część IV - Nowa nadzieja (Star Wars, 1977, reż. George Lucas), Gwiezdne wojny: Część V - Imperium kontratakuje (Star Wars: Episode V - The Empire Strikes Back, 1980, reż. Irvin Kershner), Gwiezdne wojny: Część VI - Powrót Jedi (Star Wars: Episode VI - Return of the Jedi, 1983, reż. Richard Marquand), Gwiezdne wojny: Część I - Mroczne widmo (Star Wars: Episode I - The Phantom Menace, 1999, reż. George Lucas), Gwiezdne wojny: Część II - Atak klonów (Star Wars: Episode II - Attack of the Clones, 2002, reż. George Lucas), Gwiezdne wojny: Część III - Zemsta Sithów (Star Wars: Episode III - Revenge of the Sith, 2005, reż. George Lucas). W przygotowaniu jest kolejna część sagi, która pojawi się w kinach już po oddaniu tego tekstu do druku.

${ }^{3}$ Pojęcie wprowadzone przez Henry'ego Jenkinsa (2007).

${ }^{4}$ Termin wprowadzony do dyskursu naukowego przez Alvina Tofflera (1997). Więcej o współczesnej prosumpcji i jej związku z kulturą popularną w Prosumpcja. Pomiędzy podejściem apokaliptycznym a emancypującym (Siuda, Żaglewski 2014). 
Dywersyfikując przekaz na wiele mediów, wytwórnie są w stanie dotrzeć do szerokiego grona odbiorców, a także zwielokrotnić źródła dochodów. Istotnym aspektem jest także tak zwany merchandising - czyli sprzedaż związanych z filmami zabawek i gadżetów - a rozbudowane franczyzy bardzo mu sprzyjają. W czasach, gdy wytwórnie filmowe są jedynie oddziałami międzynarodowych korporacji, filmy stają się często głównie nośnikami reklamowymi dla innych działów firmy ${ }^{5}$.

Ostatecznie fikcyjny świat przedstawiony ma o wiele większą zdolność do rozbudowy niż przygody bohatera, którego potencjał fabularny może dosyć szybko zostać wyeksploatowany. Otwiera to przed wytwórniami możliwość rozciągnięcia w czasie rozbudowanej serii filmów, które przestają być uzależnione od aktorów czy twórców.

\section{Jak zrobił to Marvel?}

Flagowym modelem shared universe jest MCU - świat tworzony na bazie postaci wywodzących się z kart komiksów wydawnictwa Marvel. W jego skład wchodzi obecnie dwanaście pełnometrażowych filmów kinowych, pięć filmów krótkometrażowych (dodanych do wydań Blu-ray), a także trzy seriale. Serię uzupełniają okazjonalne komiksy rozszerzające historie zaprezentowane $\mathrm{w}$ filmach. To właśnie ta franczyza, tworzona przez Marvel Studios należące do korporacji The Walt Disney Company, stanowi wzór w dzisiejszym kinie hollywoodzkim, który starają się naśladować producenci związani z innymi wytwórniami.

Zanim jednak w ogóle powstało studio filmowe Marvel, firma koncentrowała się na rynku komiksów, a prawa do ekranizacji przygód swoich bohaterów wydawnictwo licencjonowało podmiotom zewnętrznym. Już w 1944 roku, w dobie tak zwanych seriali kinowych, na ekrany trafiły przygody Kapitana Ameryki w odcinkach wyprodukowanych przez Republic Pictures. Następnie superbohaterowie Marvela trafili na wiele lat do telewizji, gdzie powstały popularne - aczkolwiek kiczowate - seriale i filmy, między innymi o przygodach Spider-Mana i Hulka (Dillard 2014a).

Pierwszy pełnometrażowy film kinowy oparty na postaciach z katalogu Marvel Comics powstał dopiero w 1986 roku. Był to Kaczor Howard (Howard the Duck, reż. Willard Huyck). Film, którego producentem był sam George Lucas, okazał się jednak klapą artystyczną i finansową. Dopiero w 1998 roku na podstawie komiksów wydawnictwa powstała ekranizacja doceniona zarówno przez krytykę, jak i widzów. Był to Blade - Wieczny łowca (Blade, reż. Stephen Norrington) wyprodukowany przez Amen Ra Films i dystrybuowany przez New Line Cinema. To od tego filmu, a także późniejszego o dwa lata X-Men (reż. Bryan Singer) wyprodukowanego przez 20th Century Fox zaczęła się "Złota Era filmów Marvela” (Dillard 2014b). Blade był również pierwszym filmem licencjonowanym zewnętrznej wytwórni przez Marvel Studios.

Odpowiedzialny za produkcję filmową oddział spółki Marvel Entertainment $\mathrm{w}$ pierwszych latach funkcjonowania działał jedynie jako

${ }^{5} \mathrm{O}$ tym, jak działa współcześnie system marketingowy w Hollywood, pisze Marcin Adamczak (2011: 39-49). 
współproducent - właściwą produkcją, a także dystrybucją zajmowały się inne podmioty. Sytuacja zmieniła się w 2008 roku, gdy do kin wszedł Iron Man (reż. Jon Favreu) - pierwszy samodzielnie wyprodukowany przez Marvel Studios film (Dillard 2014c). Początkowo dystrybucją zajmowały się inne firmy, jednak w 2009 roku Marvel Entertainment zostało zakupione przez The Walt Disney Company i tym samym zarówno produkcja, jak i dystrybucja filmów mogła być prowadzona przez tę samą korporację (Marvel.com, 2009).

"Ojcem chrzestnym” całej serii jest Kevin Feige - szef Marvel Studios od 2007 roku. To właśnie jemu zawdzięczamy pomysł przeniesienia uniwersum z kart komiksów wydawnictwa na ekrany kin. I to on, w kontekście wcześniejszych rozważań, może być uznany za „autora” dzieł przynależnych do omawianej franczyzy.

Zaczęło się od przeglądu praw autorskich do postaci, które ciągle są w posiadaniu Marvela, i nie zostały licencjonowane innym firmom. Okazało się, że chociaż większość najpopularniejszych superbohaterów sprzedano innym wytwórniom, studio zachowało prawa do tych mniej rozpoznawalnych, którzy wchodzą w skład grupy Avengers ${ }^{6}$. Podjęto zatem decyzję, aby spróbować wyprodukować film o Iron Manie. Produkcja okazała się sukcesem, windując przy tym postać Irona Mana na listę najpopularniejszych bohaterów Marvela.

W scenie po napisach końcowych (tak zwanych aftercredits) pojawił się Samuel L. Jackson w roli Nicka Fury'ego, który wspomniał Tony'emu Starkowi (Robert Downey Jr.) o inicjatywie Avengers. Fani komiksów nie mogli wyjść z zachwytu. Okazało się, że Marvel zaczyna przygotowania do czegoś spektakularnego - ekranizacji komiksu, która do tej pory wydawała się niemożliwa7.

Kolejnym filmem był Hulk (The Incredible Hulk, 2008, reż. Louis Leterrier). Wspomniano w nim kilkukrotnie postać Tony'ego Starka (Iron Mana) i wydarzenia przedstawione w poprzednim filmie studia. A sam Robert Downey Jr. pojawił się w króciutkiej scence po napisach. To była jedna z pierwszych, o ile w ogóle nie pierwsza w historii kina sytuacja, gdy film niebędący ani sequelem, ani rebootem odnosił się do wydarzeń przedstawionych w innej produkcji i brał je pod uwage.

W 2012 roku odbyła się premiera filmu Avengers (reż. Joss Whedon), który poprzedziły wspomniane wcześniej filmy o Iron Manie i Hulku, a także historie Thora i Kapitana Ameryki. Wszyscy ci superbohaterowie, odgrywani przez tych samych aktorów (z jednym wyjątkiem - Edwarda Nortona w roli Hulka zastąpił Mark Ruffalo), pojawili się razem na ekranie i stworzyli wielkie widowisko, które okazało się olbrzymim finansowym sukcesem studia. A zarazem zakończyło tak zwaną „pierwszą fazę" MCU, która otrzymała podtytuł Avengers Assembled.

Wspomniany na początku tekstu Ant-Man zwieńczył drugą fazę MCU. Pojawiły się w niej znane $\mathrm{z}$ wcześniejszych odsłon serii postacie Irona Mana, Thora i Kapitana Ameryki, ale widowni przedstawiono również nowych superbohaterów: Strażników Galaktyki oraz właśnie Ant-Mana. Kolejne produkcje USA.

${ }^{6}$ Podaję za filmem dokumentalnym: Marvel Studios: Assembling a Universe, 2014, ABC Studios,

${ }^{7}$ Do tej pory wydawało się to niemożliwe przede wszystkim ze względów finansowych. Brakowało także pomysłu, w jaki sposób w jednym filmie zmieścić tylu ikonicznych bohaterów komiksowych bez marginalizacji ich roli. 
ugruntowały pozycję Marvela jako lidera w segmencie kina superbohaterskiego, a sama seria MCU stała się najbardziej dochodową franczyzą w historii kina (Box Office Mojo 2015).

W 2010 roku Marvel otworzył oddział (Marvel Television), którego zadaniem jest produkcja seriali telewizyjnych. One także wchodzą w skład MCU, często rozwijając wątki poboczne zawiązane w filmach kinowych. Do tej pory wyprodukowano trzy seriale: Agentów T.A.R.C.Z.Y. (Agents of S.H.I.E.L.D., 2013) i Agentkę Carter (Agent Carter, 2015) dla telewizji ABC, a także Daredevila (2015) dla internetowej platformy Netflix. W planach są kolejne seriale.

Silna pozycja studia i jego zakotwiczenie w korporacyjnych strukturach Walta Disneya pozwoliło otwarcie nawiązać walkę z innymi wytwórniami i tym samym zdominować sektor filmów o superbohaterach. Zaczęło się od odzyskiwania sprzedanych wcześniej praw do postaci filmowych. W ten sposób do Marvela wrócili między innymi Daredevil i Punisher (Jackson 2013). Udało się także nawiązać współpracę z wytwórnią Columbia Pictures należącą do korporacji Sony, która dysponowała prawami do adaptacji przygód najpopularniejszego superbohatera wydawnictwa, czyli Spider-Mana. Tym samym powstanie wyprodukowany przez Marvel Studios film, będący częścią MCU, który następnie będzie dystrybuowany przez Columbia Pictures (Fritz 2015).

Mniej „pokojowo” przebiega rywalizacja z drugim konkurentem na rynku, należącą do korporacji Ruperta Murdocha wytwórnią 20th Century Fox. Tworzy ona własne shared universe na podstawie marvelowskich superbohaterów związanych z grupą X-Men, ma również prawa do Fantastycznej Czwórki.

Jedną ze spornych kwestii są prawa do rodzeństwa superbohaterów Quicksilvera i Scarlett Witch, którzy pojawili się zarówno w filmie wyprodukowanym przez 20th Century Fox - X-Men: Przeszłość, która nadejdzie (X-Men: Days of Future Past, 2014, reż. Bryan Singer), jak i w superprodukcji Marvela-Avengers: Czar Ultrona (Avengers: Age of Ultron, 2015, reż. Joss Whedon). Są oni członkami grup X-Men i Avengers, zatem prawa do nich miały oba studia. Pojawił się jednak problem dotyczący ich charakterystyki - w komiksach są mutantami, dziećmi Magneta. Marvel jednak w swoim filmie nie mógł o tym wspomnieć, gdyż prawa do komiksowej koncepcji mutantów oraz postaci Magneta są w rękach Foxa (Kendrick 2015). Postanowiono więc na łamach komiksów przedstawić ich nową biografię, według której nie są już mutantami (bliżej im do grupy Inhumans, objętej prawami przez Marvela), a ich ojcem nie jest już Magneto (Steinbeiser 2015). Tym samym komiksowe pierwowzory zbliżyły się do swoich filmowych wcieleń.

Rywalizacja Marvela z 20th Century Fox ma także swoje „ofiary”. W krótkim czasie wydawnictwo zakończyło publikować komiksy o Fantastycznej Czwórce (Schedeen 2014) oraz uśmierciło popularnych superbohaterów: Wolverine'a (Franich 2014) i Deadpoola (McMillan 2014). Tak się składa, że prawa do tych postaci ma Fox, który przygotowuje filmy bazujące na ich przygodach... 


\section{Cechy Marvel Cinematic Universe}

Chociaż w budowie Marvel Cinematic Universe aspekty prawnoautorskie oraz finansowe odgrywają olbrzymią rolę, to same filmy także wyróżniają się charakterystycznym stylem oraz wypracowały szereg rozpoznawalnych konwencji.

Filmy Marvel Studios stanowią przeniesienie formatu wydawniczego znanego z komiksów na pole filmu i telewizji. Najważniejsi superbohaterowie mają własne filmy (a nawet serie filmów) tak, jak są bohaterami własnych serii komiksów, od czasu do czasu występując gościnnie w mniejszej roli w historii innej postaci. Na równych zasadach spotykają się za to w dużym crossoverze, którym w ramach MCU są filmy o grupie Avengers.

Za produkcje odpowiadają różne ekipy, dlatego też studio nie jest ograniczone chronologią i może realizować równolegle kolejne filmy. Same historie nie są ściśle powiązane, tylko pojedyncze sceny stanowią odwołania do innych części cyklu. Dominuje zasada, że każdy film lub serial muszą bronić się samodzielnie, ale także pasować do uniwersum.

Kolejne premiery cyklu są zaplanowane na kilka lat do przodu. Taka długofalowa strategia służy opracowaniu kierunku, w jakim ma toczyć się historia uniwersum. Twórcy, którzy podejmują się realizacji konkretnego filmu, wiedzą, jak poprowadzić opowieść, aby była pewnym wstępem do wydarzeń prezentowanych w następnych filmach.

W związku z wieloletnimi planami studia umowy z aktorami wcielającymi się w postacie superbohaterów także są podpisywane na kilka produkcji do przodu. Robert Downey Jr. w postać Tony'ego Starka/Iron Mana wcielił się dotychczas sześć razy, Chris Evans zagrał pięć razy Kapitana Amerykę, a Chris Hemsworth cztery razy Thora. Rośnie też znaczenie postaci drugo- i trzecioplanowych, które mimo braku własnych filmów stanowią ważną część uniwersum. I tak Samuel L. Jackson pojawił się jako Nick Fury w siedmiu filmach i kilku odcinkach serialu Agenci T.A.R.C.Z.Y., Clark Gregg jako Agent Coulson wystąpił w czterech filmach pełnometrażowych, dwóch krótkometrażowych, a także jest głównym bohaterem wspomnianego serialu, Scarlett Johansson natomiast została czterokrotnie Czarną Wdową.

Nastrój filmów spod szyldu MCU i ich generalna stylistyka wpisują się w nurt znany w polskim filmoznawstwie jako Kino Nowej Przygody (Szyłak 2011: 5-19). To przepełnione akcją i humorem wielkie widowiska, w których superbohaterowie bronią świat przed zagrożeniami. Fabuła przeważnie kończy się bombastycznym finałem, w którym tryumfują protagoniści, a siły zła zostają przezwyciężone. Tym samym filmy MCU realizują strategię blockbusterów (Jajko 2015: 23-39).

Marvel przy okazji kolejnych produkcji serii tworzy także hybrydy gatunkowe, mieszając znane schematy i ikonografie z superbohaterskimi motywami. Filmy o Iron Manie to wariacja na temat kina science fiction, produkcje $\mathrm{z}$ Thorem wpisują się w nurt fantasy, Kapitan Ameryka jest bohaterem filmu wojennego (część pierwsza) oraz thrillera szpiegowskiego (część druga), Strażnicy Galakty$k i$ to odmiana space opery, a Ant-Man - heist movie. Widzowie zatem za każdym razem otrzymują coś nowego, chociaż wpisanego w ogólnie rozpoznawalną stylistykę serii. 
Stałymi elementami każdego z filmów MCU są sceny w trakcie napisów końcowych (midcredits) oraz po ich zakończeniu (aftercredits). Przedstawiciele studia żartują: "Marvel nauczył widzów zostawać w kinie do końca napisów” (Marvel Studios: Assembling a Universe 2014). Ponadto tradycyjnie w każdym filmie pojawia się gościnnie (tak zwany cameo) w różnych rolach Stan Lee - pomysłodawca większości superbohaterów Marvela.

MCU stanowi również sztandarowy przykład narracji transmedialnej. Świat ten jest rozbudowywany nie tylko w filmach pełnometrażowych, ale swoje wątki rozwija także w serialach, filmach krótkometrażowych oraz w powiązanych z nimi komiksach. Być może w przyszłości dołączą do nich również animacje i gry wideo.

\section{Co dalej?}

Model shared universe, który został rozwinięty i udoskonalony przez wytwórnię Marvel, jest wzorem dla innych producentów hollywoodzkich. W związku z olbrzymimi zyskami, jakie ta strategia biznesowa przynosi wytwórniom, możemy być pewni, że w najbliższych latach bardzo często będziemy słyszeć określenie shared universe. Tym bardziej, że już nie tylko nowe serie obierają ten kierunek rozwoju, ale i klasyczne franczyzy zaczynają być modyfikowane, aby sprostać nowym standardom. Z całą pewnością więc widzowie na całym świecie zostaną obdarowani nowymi produktami, które już doskonale znają.

\section{Literatura:}

Adamczak M., 2010, Globalne Hollywood, filmowa Europa i polskie kino po 1989 roku, Gdańsk: Słowo/obraz terytoria.

Adamczak M., 2011, System marketingowy Hollywood w latach 1977-2011 [w:] Kino Nowej Przygody, red. J. Szyłak, Gdańsk: Słowo/obraz terytoria.

Box Office Mojo, 2015, Movie Franchises and Brands Index, http://www.boxofficemojo.com/ franchises $/$ ?view $=$ Franchise $\&$ sort $=$ sumgross \&order $=$ DESC\&p $=$.htm $[$ dostęp: 16.08.2015].

Cecchini M., 2015, Full Marvel Movie Release Calendar, http://www.denofgeek.us/movies/ marvel/237462/full-marvel-movie-release-calendar [dostęp: 16.08.2015].

Collinson G., 2015, The Future of Franchising: The Shared Universe, http://www.flickeringmyth.com/2015/03/the-future-of-franchising-the-shared-universe.html [dostęp: 16.08.2015].

Coolidge B., 2013, The Intricate, Expansive Universe of Quentin Tarantino, http://uk.ign.com/ articles/2013/01/17/the-intricate-expansive-universe-of-quentin-tarantino [dostęp: 16.08.2015].

Dillard Ch., 2014a, History of Marvel Studios - Part 1, http://news.comicui.com/2014/03/history-of-marvel-studios-part-1/ [dostęp: 16.08.2015].

Dillard Ch., 2014b, History of Marvel Studios - Part 2, http://news.comicui.com/2014/04/history-of-marvel-studios-part-2/ [dostęp: 16.08.2015].

Dillard Ch., 2014c, History of Marvel Studios - Part 3, http://news.comicui.com/2014/04/history-of-marvel-studios-part-3/ [dostęp: 16.08.2015].

Franich D., 2014, Marvel is killing off a major character - EXCLUSIVE FIRST LOOK!, http://www. ew.com/article/2014/04/25/death-wolverine-marvel-exclusive> [dostęp: 16.08.2015]. 
Fritz B., 2015, Marvel and Sony Reach Deal on Spider-Man Movie Production, http://www. wsj.com/articles/marvel-and-sony-reach-deal-on-spider-man-movie-production-1423546677 [dostęp: 16.08.2015].

Helman A., 2010, Teoria autorska [w:] Historia myśli filmowej. Podręcznik, red. A. Helman, J. Ostaszewski, Gdańsk: Słowo/obraz terytoria.

Jackson M., 2013, 3 other superheroes just joined Daredevil back at Marvel Studios, http://www. blastr.com/2013-5-2/3-other-superheroes-just-joined-daredevil-back-marvel-studios [dostęp: 16.08.2015].

Jajko K., 2015, Nadmiar na sprzedaż. Wstęp do opisu paradygmatu kina blockbusterowego [w:] Paradygmaty wspótczesnego kina, red. R.W. Kluszczyński, T. Kłys, N. Korczarowska-Różycka, Łódź: Wydawnictwo Uniwersytetu Łódzkiego.

Jenkins H., 2007, Kultura konwergencji. Zderzenie starych $i$ nowych mediów, Warszawa: Wydawnictwa Akademickie i Profesjonalne.

Kendrick B., 2015, Avengers vs. X-Men Quicksilver: Marvel \& Fox Movie Usage Explained, http:// screenrant.com/quicksilver-x-men-avengers-2-fox-marvel-dead/ [dostęp: 16.08.2015].

Marvel.com, 2009, Disney to Acquire Marvel Entertainment, http://marvel.com/news/comics/9360/disney_to_acquire_marvel_entertainment [dostęp: 16.08.2015].

Marvel Studios: Assembling a Universe, 2014, prod. ABC Studios, USA.

McMillan G., 2014, Marvel Exec Teases Comic Book Death of Deadpool, http://www.hollywoodreporter.com/heat-vision/marvel-exec-teases-comic-book-734749 [dostęp: 16.08.2015].

Parrish R., 2015, How Many Connected Movie Universes Are There Now?, http://www.techtimes.com/articles/48137/20150424/how-many-connected-movie-universes-arethere-now.htm [dostęp: 16.08.2015].

Schedeen J., 2014, NYCC: Marvel Cancels Fantastic Four Comic, http://uk.ign.com/articles/2014/10/12/nycc-marvel-cancels-fantastic-four-comic [dostęp: 16.08.2015].

TV Tropes, 2015, Shared Universe, http://tvtropes.org/pmwiki/pmwiki.php/Main/SharedUniverse [dostęp: 22.07.2015].

Siuda P., Żaglewski T (red.), 2014, Prosumpcja. Pomiędzy podejściem apokaliptycznym a emancypującym, Gdańsk: Wydawnictwo Naukowe Katedra.

Steinbeiser A., 2015, Scarlet Witch \& Quicksilver Confirmed As Not Being Mutants, True Parents Revealed, http://comicbook.com/2015/05/09/-scarlet-witch-quicksilvers-confirmed-asnot-being-mutants-true-/ [dostęp: 16.08.2015].

Szyłak J., 2011, Kino Nowej Przygody - jego cechy i granice [w:] Kino Nowej Przygody, red. J. Szyłak, Gdańsk: Słowo/obraz terytoria.

Toffler A., 1997, Trzecia fala, tłum. E. Woydyłło, Warszawa: Państwowy Instytut Wydawniczy.

Skład Marvel Cinematic Universe (w kolejności chronologicznej)

Filmy pełnometrażowe:

Iron Man, 2008, reż. J. Favreau, scen. M. Fergus, H. Ostby, A. Marcum i M. Holloway, prod. A. Arad i K. Feige, USA.

Incredible Hulk, 2008, reż. L. Leterrier, scen. Z. Penn, prod. A. Arad, G. Anne Hurd i K. Feige, USA.

Iron Man 2, 2010, reż. J. Favreau, scen. J. Theroux, prod. K. Feige, USA.

Thor, 2011, reż. K. Branagh, scen. A. E. Miller, Z. Stentz i D. Payne, prod. K. Feige, USA.

Captain America: Pierwsze starcie (Captain America: The First Avenger), 2011, reż. J. Johnston, scen. C. Markus i S. McFeely, prod. K. Feige, USA.

The Avengers, 2012, reż. i scen. J. Whedon, prod. K. Feige, USA.

Iron Man 3, 2013, reż. S. Black, scen. D. Pierce i S. Black, prod. K. Feige, USA, Chiny.

Thor: Mroczny świat (Thor: The Dark World), 2013, reż. A. Taylor, scen. C. Yost, C. Markus i S. McFeely, prod. K. Feige, USA.

Kapitan Ameryka: Zimowy żotnierz (Captain America: The Winter Soldier), 2014, reż. A. i J. Russo, scen. C. Markus i S. McFeely, prod. K. Feige, USA. 
Strażnicy Galaktyki (Guardians of the Galaxy), 2014, reż. J. Gunn, scen. J. Gunn i N. Perlman, prod. K. Feige, USA.

Avengers: Czas Ultrona (Avengers: Age of Ultron), 2015, reż. i scen. J. Whedon, prod. K. Feige, USA.

Ant-Man, 2015, reż. P. Reed, scen. E. Wright, J. Cornish, A. McKay i P. Rudd, prod. K. Feige, USA.

Filmy krótkometrażowe:

Marvel One-Shot: Konsultant (Marvel One-Shot: The Consultant), 2011, reż. Leythum, scen. E. Pearson, prod. K. Feige, USA.

Marvel One-Shot: Ciekawa rzecz spotkała nas przy młocie Thora (Marvel One-Shot: A Funny Thing Happened On The Way to Thor's Hammer), 2011, reż. Leythum, scen. E. Pearson, prod. K. Feige, USA.

Marvel One-Shot: Przedmiot 47 (Marvel One-Shot: Item 47), 2012, reż. L. D’Esposito, scen. E. Pearson, prod. K. Feige, USA.

Marvel One-Shot: Agent Carter, 2013, reż. L. D’Esposito, scen. E. Pearson, prod. K. Feige, USA.

All Hail the King, 2014, reż. i scen. D. Pearce, prod. K. Feige, USA.

Seriale:

Agenci T.A.R.C.Z.Y. (Agents of S.H.I.E.L.D.), 2013, prod. ABC, USA.

Agentka Carter (Agent Carter), 2015, prod. ABC, USA.

Daredevil, 2015, prod. Netflix, USA.

\section{Abstrakt}

Shared universe jest modelem biznesowym, który skutecznie zdobywa popularność w hollywoodzkim przemyśle filmowym. Niniejszy artykuł stanowi próbę wyjaśnienia tego fenomenu, a także opis jego cech, wad i zalet. Aspekty praktyczne zostaną omówione na przykładzie Marvel Cinematic Universe - serii filmów wyprodukowanych przez wytwórnię Marvel Studios.

\section{Słowa kluczowe}

przemysł filmowy, kino hollywoodzkie, narracja transmedialna, franczyzy medialne, prawa autorskie

\section{Summary}

\section{Marvel Makes Films. Shared Universe as a New Trend in Hollywood Cinema}

Shared universe is a business model that effectively gaining popularity in the Hollywood film industry. This article attempts to explain this phenomenon, as well as describe its features, advantages and disadvantages. Practical aspects will be presented on the example of Marvel Cinematic Universe - a series of films produced by Marvel Studios.

\section{Keywords}

film industry, Hollywood cinema, transmedia storytelling, media franchises, copyrights 